\title{
Pengaruh lama perendaman dan persentase carboxymethyl cellulose (CMC) terhadap karakteristik susu kecambah kedelai (Glysine max (L.) Merr.)
} Effect of longer damaging and percentage of carboxymethyl cellulose (CMC) against
characteristic of soy milk district (Glysine max (L.) Merr.)

\author{
Deny Utomo $^{1)}$ *, Lailatul Rizkiyah ${ }^{1)}$ \\ ${ }^{1}$ Prodi Ilmu dan Teknologi Pangan, Fakultas Pertanian, Universitas Yudharta Pasuruan \\ E-mail : denyut369@gmail.com \\ Informasi artikel: \\ Dikirim: 07/08/2020; ditinjau: 07/08/2020; disetujui: 03/09/2020
}

\begin{abstract}
Soy-based drinks are an alternative source of high-quality vegetable protein and have almost the same content as cow's milk but do not contain lactose which can cause digestive problems in some people (lactose intolerance). Nutrition value and quality in legumes will be better after going through the germination process. This study aims to determine the effect of soybean seed soaking time and the percentage of stabilizer Carboxymethyl Cellulose (CMC) on the best chemical, physical and olganoleptic quality in soybean sprouts milk. The method used in the study of soybean sprouts milk is Random Factorial Design (RCBD) which consists of 2 factors: soaking time (4 hours, 8 hours and 12 hours) and the percentage ofstabilizers Carboxymethyl Cellulose (CMC) $(0.4 \%$ and 0,6\%). Each treatment was repeated 3 times so 18 trials were obtained. The tests included chemical tests including protein content and antioxidant activity, physical including viscosity and organoleptics including color, the flavor, texture and taste. Analysis of chemical and physical content data is done using the Minitab application to search fordata Analysis of Variance and to determine the notation using the Tukey Method. While the organoleptic test uses the Friedman method and to find the best treatment using the Effectiveness Index. The best research results on soybean sprouts milk on chemical, physical and organoleptic content were found in the P1C1 treatment (4 hours immersion time and 0,4\% CMC percentage) with protein analysis results with a value of 4.97, antioxidant activity with a value of 45.75, viscosity with a value of 19.73, color with a value of 35.33 (likes), the flavor with a value of 3.50 (somewhat like), texture with a value of 3.20 (somewhat like) and taste with a value of 3.63 (like).
\end{abstract}

Keywords: carboxymethyl cellulose $(\mathrm{cmc})$, immersion time, protein

\begin{abstract}
ABSTRAK
Minuman berbasis kedelai merupakan alternatif sumber protein nabati yang berkualitas tinggi dan mempunyai kandungan yang hampir sama dengan susu sapi namun tidak mengandung laktosa yang dapat menyebabkan masalah pencernaan pada sebagian orang (lactose intolerance). Nilai dan mutu gizi pada kacang-kacangan akan menjadi lebih baik setelah melalui proses perkecambahan (Wea, Widodo, dan Pratomo, 2014). Penelitian ini bertujuan untuk mengetahui pengaruh lama perendaman biji kedelai dan persentase penstabil Carboxymethyl Cellulose (CMC) terhadap mutu kimia, fisik dan olganoleptik terbaik pada susu kecambah kedelai. Metode yang digunakan dalam penelitian susu kecambah kedelai yaitu Rancangan Acak Kelompok (RAK) Faktorial
\end{abstract}


yang teridiri dari 2 faktor yaitu lama perendaman (4 jam, 8 jam dan 12 jam) dan persentase penstabil Carboxymethyl Cellulose (CMC) (0,4\% dan 0,6\%). Masing-masing perlakuan diulang sebanyak 3 kali sehingga diperoleh 18 kali percobaan. Uji yang dilakukan meliputi uji kimia meliputi kadar protein dan aktivitas antioksidan, fisik meliputi viskositas dan organoleptik meliputi warna, aroma, tekstur dan rasa. Analisa data kandungan kimia dan fisik dilakukan dengan menggunakan aplikasi Minitab untuk mencari data Analysis of Variance dan untuk menentukan notasi menggunakan Tukey Method. Sedangkan uji organoleptik menggunakan metode Friedman dan untuk mencari perlakuan terbaik menggunakan metode Indeks Efektifitas. Hasil penelitian terbaik pada susu kecambah kedelai terhadap kandungan kimia, fisik dan organoleptik terdapat pada perlakuan P1C1 (lama perendaman 4 jam dan prosentase CMC 0,4\%) dengan hasil analisa protein dengan nilai 4,97, aktivitas antioksidan dengan nilai 45,75, viskositas dengan nilai 19,73, warna dengan nilai 35,33 (suka), aroma dengan nilai 3,50 (agak suka), tekstur dengan nilai 3,20 (agak suka) dan rasa dengan nilai 3,63 (suka).

Kata kunci: carboxymethyl cellulose $(\mathrm{cmc})$, lama perendaman, protein

\section{PENDAHULUAN}

Minuman berbasis kedelai biasanya disebut dengan susu kedelai atau soymilk. susu kedelai merupakan salah satu produk olahan yang terbuat dari ekstrak biji kedelai Glysine max (L.) Merr. yang merupakan alternatif sumber protein nabati yang berkualitas tinggi dan mempunyai nutrisi gizi yang seimbang (Durazzo et al., 2015; Anggono \& Wahyuni, 2017). Mardiyanto dan Sudarwati (2015), menyatakan bahwa beberapa varietas kedelai di Indonesia mempunyai kadar protein 30,53\%-44\% dan kadar lemak 7,5\%-20,9\%. Selain mengandung protein yang tinggi, kedelai juga mengandung senyawa isoflavon yang termasuk dalam senyawa flavonoid yang berfungsi sebagai antioksidan (Astuti, 2012).

Kedelai merupakan family dari kacang-kacangan (Leguminoceae) yang telah diketahui nilai dan mutu gizi kacangkacangan akan menjadi lebih baik setelah melalui proses perkecambahan (Aminah dan Hersoelistyorini, 2012). Adapun reaksi yang terjadi selama proses perkecambahan meliputi beberapa tahap, yaitu hidrolisis, oksidasi dan sintesis (Jiang et al., 2013). Reaksi hidrolisis dimulai dari proses awal perkecambahan yaitu imbibisi air. Proses imbibisi air kedalam biji dapat mengaktifkan anzim-enzim endogen seperti protease. Protease menghidrolisis protein menjadi peptide dan asam amino, sehingga protein tersebut menjadi lebih sederhana dan lebih mudah dicerna (Mardiyanto dan Sudarwati, 2015).

Susu kecambah kedelai merupakan salah satu produk olahan kedelai dengan melalui proses perkecambahan untuk dapat meningkatkan kandungan gizi seperti kandungan protein (Pramita, 2017). Proses pembuatan susu kecambah kedelai melalui beberapa tahapan yaitu persiapan bahan dengan melalui tahap penyortiran, pencucian, perendaman, inkubasi, pengkulitan, penggilingan, kemudian penyaringan sehingga diperoleh susu kecambah kedelai (Cahyani, 2015). Penamanasan atau sterilisasi dilakukan pada akhir proses pembuatan. Pemanasan ini bertujuan untuk mematikan organisme yang bersifat patogen yang dapat mengubah cita rasa dan kandungan susu.

Sebagai produk hasil olahan, mutu susu kecambah kedelai ditentukan oleh kandungan gizi dan kenampakan serta flavour (cita rasa) yang spesifik (Tripamungkas, 2015). Masalah yang sering dijumpai dalam proses pembuatan susu kedelai salah satunya adalah adanya endapan pada sistem dispersi minuman susu kedelai. Carboxymethyl cellulose (CMC) merupakan salah satu zat yang dapat mempertahankan kestabilan minuman agar partikel padatannya tetap terdispersi merata ke seluruh bagian sehingga minuman tidak mengalami pengendapan (Prasetya et al., 2015). 
Pada penelitian sebelumnya umur perkecambahan 0-72 jam diketahui kadar protein meningkat pada kecambah berumur 24 jam, sedangkan pada umur setelah 24 jam kadar protein menurun namun nilai cerna protein semakin meningkat (Mardiyanto dan Sudarwati, 2015). Pernyataan ini diperkuat dengan pernyataan Pertiwi (2013), yang menyatakan bahwa kadar protein menurun pada lama perkecambahan 48 jam dengan variasi lama perkecambahan 0-48 jam. Berdasarkan penelitian sebelumnya, penelitian yang berjudul "Pengaruh Lama Perendaman dan Persentase Carboxymethyl Cellulose (CMC) Terhadap Karakteristik Susu Kecambah Kedelai (Glysine max (L.) Merr). yang terbaik belum diketahui sehingga peneliti ini bertujuan untuk mengetahui lama perendaman dan persentase CMC yang terbaik dan perlakuan terbaik dilihat dari sifat kimia, fisik dan organoleptik pada susu kecambah kedelai.

\section{METODE}

\section{Bahan}

Bahan yang digunakan dalam pembuatan susu kecambah kedelai adalah kedelai kuning yang diperoleh dari pasar sukorejo, CMC (Carboxymethyl Cellulose) didapat dari toko Gunawancandra dan air (sumur). Sedangkan bahan yang digunakan untuk analisa kimia adalah Folin-Ciocalteau, tyrosine, tryptophan, Alumunium foil, DPPH (1,1-diphenyl-2-picrylhydrazil), kuarsetin, methanol p.a, aquades, pereaksi A $(50 \mathrm{ml}$ $\mathrm{Na} 2 \mathrm{CO} 32 \%$ dalam $\mathrm{NaOH} 0,1 \mathrm{~N}+1 \mathrm{ml}$ CuSO4 0,5\% dalam Na K tartrat), pereaksi B (Follin wu).

Alat

Alat yang digunakan adalah timbangan dapur digunakan untuk menimbang kedelai, timbangan analitik (Kabuto) digunakan untuk menimbang $\mathrm{CMC}$, baskom untuk merendam, baskom plastik berlubang untuk menginkubasi kedelai yang sudah direndam, gelas ukur untuk mengukur air, blander (Cosmos cb-522) untuk meghancurkan kedelai menjadi bubur dan untuk menghomogenkan CMC, kain saring untuk memisahkan sari dan ampas, saringan plastik untuk menyaring susu yang telah dihomogenkan dengan CMC, panci digunakan untuk mensterilisasi susu kedelai, kompor digunakan sebagai alat pemanas atau pembakar, spatula digunakan untuk mengaduk susu ketika disterilisasi, sendok alumunium digunakan untuk mengambil dan memasukkan CMC, corong plastik digunakan untuk memasukkan susu pada botol, botol plastik digunakan sebagai wadah untuk menyimpan susu kecambah kedelai. Alat yang digunakan dalam analisa fisika kimia adalah gelas (Pyrex), mikropipet, seperangkat alat sentrufuge, spektrofotometri UV-Vis, timbangan analitik, tabung reaksi, rak tabung reaksi, labu takar, mikro pipet, pipet tetes, pipet volumetri, spektrofotometri dan NDJ-1 viscometer. Adapun alat yang digunakan untuk analisis organoleptik susu kecambah kedelai terdiri dari gelas dan sendok.

\section{Metode pelaksanaan}

Metode yang digunakan dalam penelitian ini menggunakan Rancangan Acak Kelompok (RAK) Faktorial yang terdiri dari 2 faktor yaitu: lama perendaman (4 jam, 8 jam dan 12 jam) dan persentase CMC (4\% dan $6 \%$ ), sehingga didapatkan 6 kombinasi perlakuan. Setiap perlakuan dilakukan 3 kali pengulangan seperti pada tabel 1 .

Tabel 1. Desain pelaksanaan

\begin{tabular}{cccc}
\hline \multirow{2}{*}{ Perlakuan } & \multicolumn{3}{c}{ Ulangan } \\
\cline { 2 - 4 } & I & II & III \\
\hline P1C1 & U1 & U2 & U3 \\
P1C2 & U1 & U2 & U3 \\
P2C1 & U1 & U2 & U3 \\
P2C2 & U1 & U2 & U3 \\
P3C1 & U1 & U2 & U3 \\
P3C2 & U1 & U2 & U3 \\
\hline
\end{tabular}

Keterangan:

$\mathrm{P} 1 \mathrm{C} 1=$ lama perendaman 4 jam dan persentase CMC 4\%

$\mathrm{P} 1 \mathrm{C} 2$ = lama perendaman 4 jam dan persentase CMC 6\%

$\mathrm{P} 2 \mathrm{C} 1=$ lama perendaman 8 jam dan persentase CMC 4\%

$\mathrm{P} 2 \mathrm{C} 2=$ lama perendaman 8 jam dan persentase CMC 6\% 
$\mathrm{P} 3 \mathrm{C} 1$ = lama perendaman 12 jam dan persentase CMC $4 \%$

$\mathrm{P} 3 \mathrm{C} 2=$ lama perendaman 12jam dan persentase CMC 6\%

Proses pembuatan susu kecambah kedelai melalui 2 tahap yaitu tahap 1 perkecambahan biji kedelai dan tahap 2 pembuatan susu kecambah kedelai dan penambahan Carboxymethyl Cellulose (CMC).

Tahap 1 perkecambahan biji kedelai antara lain sebagai berikut:

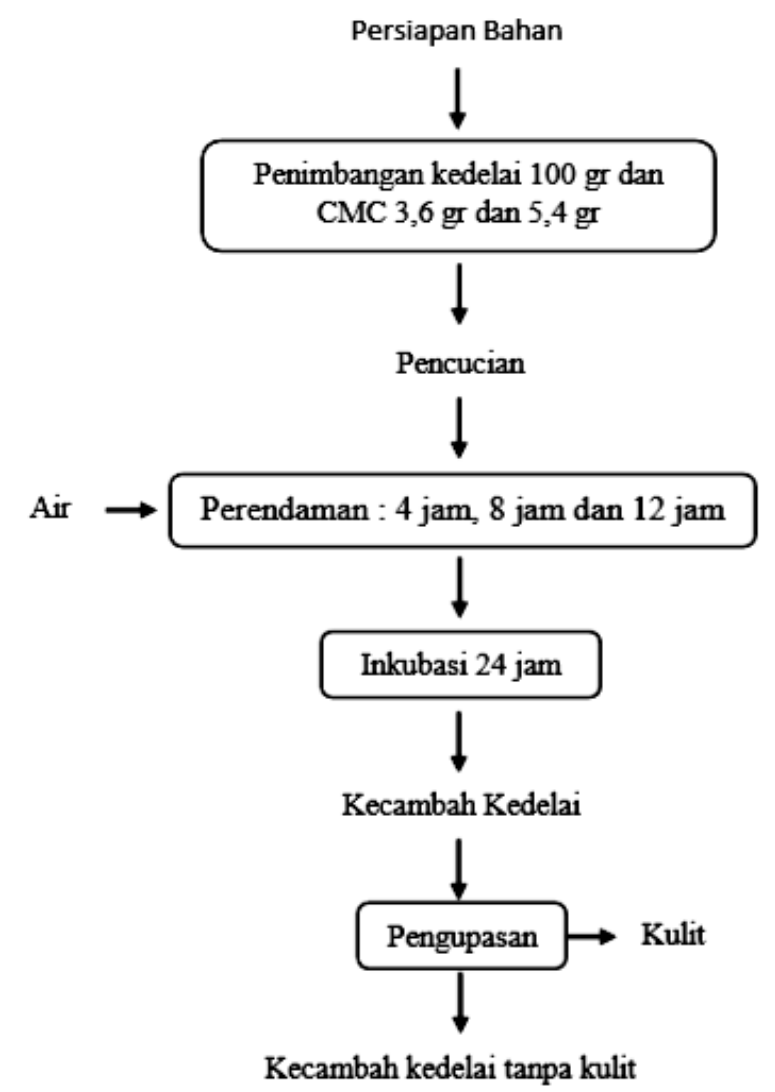

Gambar 1. Diagram alir perkecambahan biji kedelai
Tahap 2 pembuatan susu kecambah kedelai antara lain sebagai berikut:

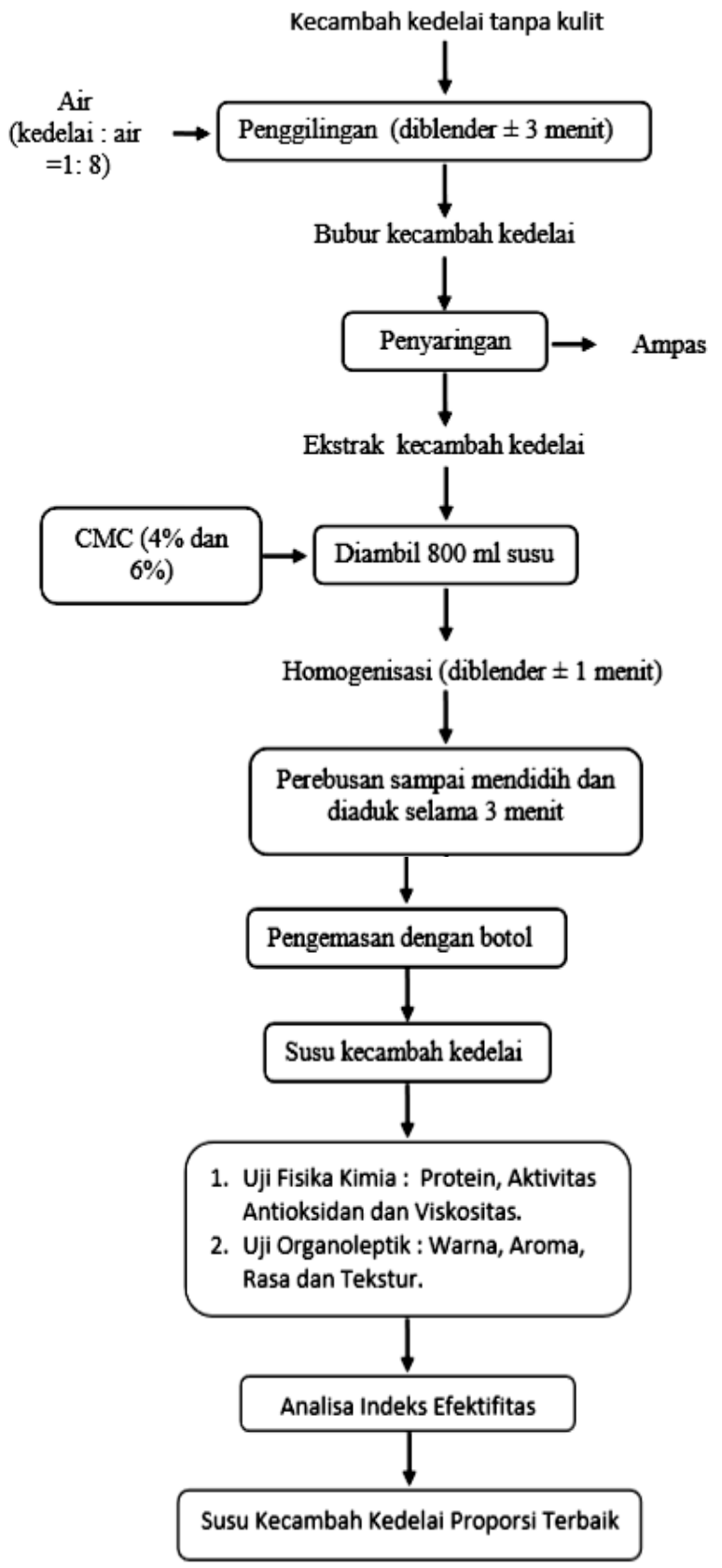

Gambar 2. Diagram alir pembuatan susu kecambah kedelai

\section{Metode pengumpulan data}

Metode pengumpulan data yang digunakan pada penelitian ini adalah dengan melakukan pengamatan pada sifat kimia, fisik dan organoleptik. Analisis yang dilakukan pada susu kecambah kedelai terhadap sifat kimia meliputi kadar protein dengan metote lowry dan aktivitas antioksidan DPPH (Huang, 2005). Analisis terhadap sifat fisik dilakukan pada viskositas 
susu kecambah menggunakan alat (NDJ-1 Viscometer). Sedangkan analisis organoleptik meliputi warna, aroma, tekstur dan rasa. Uji skor (hedonic) dalam penelitian ini menggunakan 30 panelis tidak terlatih dengan komposisi panelis pria sama dengan panelis wanita. Skala hedonic dalam uji organoleptik susu kecambah kedelai disajikan dalam bentuk angka dengan rentan 1 (Sangat tidak suka) sampai 5 (sangat suka).

\section{Metode analisa data}

Dalam penelitian ini analisa data fisika kimia dilakukan dengan menggunakan aplikasi Mini Tab untuk mencari data Analysis of Variance dan untuk menentukan notasi menggunakan Tukey Method. Untuk uji organoleptik menggunakan uji friedman dan untuk mencari perlakuan terbaik pada analisa fisika kimia dan organoleptik menggunakan uji Indeks Efektifitas De Garmo et al. (1984) yang dimodifikasi oleh Susrini (2003).

\section{HASIL DAN PEMBAHASAN}

\section{Analisa kadar protein}

Pengujian kadar protein dalam penelitian ini menggunakan metode lowry. Berdasarkan hasil analis sidik ragam menunjukkan bahwa adanya pengaruh tidak beda nyata antara kombinasi perlakuan lama perendaman dan persentase carboxymethyl cellulose (CMC) terhadap kadar protein susu kecambah kedelai yang dihasilkan. Rerata kadar protein pada berbagai kombinasi perlakuan dapat dilihat pada tabel 2. Pada tabel 2 menunjukkan bahwa rerata kadar protein pada susu kecambah kedelai dengan kombinasi perlakuan lama perendaman dan persentase CMC berkisar antara 2,11a sampai 4,97d. Kadar protein tertinggi diperoleh pada kombinasi perlakuan lama perendaman 4 jam dan persentase CMC 0,4\% (P1C1) yaitu 4,97d dan kadar protein terendah diperoleh pada kombinasi perlakuan lama perendaman 12 jam dan persentase CMC 0,6\% (P3C2) yaitu 2,11a.
Tabel 2. Rerata kadar protein (\%)

\begin{tabular}{lc}
\hline \multicolumn{1}{c}{ Kombinasi Perlakuan } & \multicolumn{1}{c}{$\begin{array}{c}\text { Rerata } \\
\text { Protein } \\
(\%)\end{array}$} \\
\hline \hline $\begin{array}{l}\text { P3C2 (Lama Perendaman 12 } \\
\text { jam, CMC 0,6\%) }\end{array}$ & $2,11 \mathrm{a}$ \\
$\begin{array}{l}\text { P2C2 (Lama Perendaman } 8 \\
\text { jam, CMC 0,6\%) }\end{array}$ & $2,59 \mathrm{~b}$ \\
$\begin{array}{l}\text { P3C1 (Lama Perendaman 12 } \\
\text { jam, CMC 0,4\%) }\end{array}$ & $2,62 \mathrm{~b}$ \\
$\begin{array}{l}\text { P2C1 (Lama Perendaman } 8 \\
\text { jam, CMC 0,4\%) }\end{array}$ & $2,72 \mathrm{~b}$ \\
$\begin{array}{l}\text { P1C2 (Lama Perendaman } 4 \\
\text { jam, CMC 0,6\%) }\end{array}$ & $4,12 \mathrm{c}$ \\
$\begin{array}{l}\text { P1C1 (Lama Perendaman 4 } \\
\text { jam, CMC 0,4\%) }\end{array}$ & $4,97 \mathrm{~d}$ \\
\hline
\end{tabular}

Keterangan: Angka rerata yang diikuti dengan notasi huruf yang sama menunjukkan pengaruh tidak beda nyata pada uji Tukey

Tabel 2 menunjukkan bahwa uji Tukey masing-masing perlakuan menunjukkan pengaruh tidak beda nyata dengan notasi yang sama. Rerata kadar protein susu kecambah kedelai juga dapat dilihat pada gambar 3 dibawah ini.

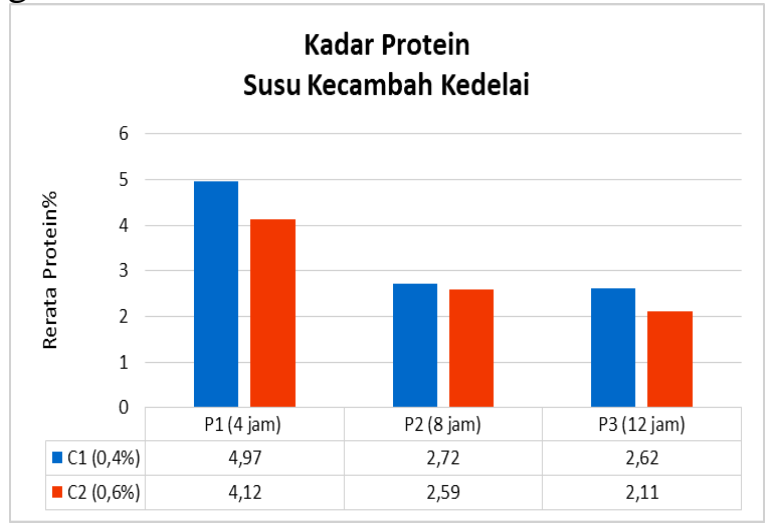

Gambar 3. Rerata kadar protein (\%)

Gambar 3 menunjukkan bahwa semakin lama perendaman maka kadar protein pada susu kecambah kedelai semakin menurun. Hal ini disebabkan karena semakin lama perendaman maka kadar protein semakin menurun, komponen protein larut dalam air sehingga ikatan struktur protein lepas (Suhaidi, 2003). Gambar 3 juga menunjukkan bahwa semakin banyak persentase CMC yang ditambahkan, maka kadar protein susu kecambah kedelai semakin menurun. Hal ini tidak sesuai 
dengan literatur, Alakali et al, (2008) menyatakan bahwa CMC tidak mengandung protein. Penurunan kadar protein susu kecambah kedelai disebabkan kemasan penyimpanan berupa botol plastik, suhu dan kelembaban produk yang tidak sesuai serta lama penyimpanan bahan yang tidak langsung diuji diduga menyebabkan menurunnya jumlah kadar protein susu kecambah kedelai. Mengingat produk susu merupakan produk yang rentan pada kerusakan dan menurunnya nilai gizi didalamnya. Codex (2004) menyatakan bahwa shelf life produk susu dipengaruhi oleh beberapa faktor, seperti: kendali mutu mikrobiologis yang diterapkan (suhu penyimpanan), metode pendinginan selama penanganan dan proses produksi, jenis kemasan yang digunakan serta potensi atau kemungkinan kontaminasi pasca proses produksi.

\section{Analisa aktivitas antioksidan}

Pengujian aktivitas antioksidan dalam penelitian ini menggunakan metode DPPH (2,2-difenil-1-pikrilhidrazil) (Huang, 2005). Berdasarkan hasil analis sidik ragam menunjukkan bahwa adanya pengaruh beda nyata antara kombinasi perlakuan lama perendaman dan persentase carboxymethyl cellulose (CMC) terhadap aktivitas antioksidan susu kecambah kedelai yang dihasilkan. Rerata hasil uji aktivitas antioksidan dapat dilihat pada tabel 3. Pada tabel 3 menunjukkan bahwa rerata aktivitas antioksidan pada susu kecambah kedelai dengan kombinasi perlakuan lama perendaman dan persentase CMC berkisar antara 11,22a sampai 45,75e. Aktivitas antioksidan tertinggi diperoleh pada kombinasi perlakuan lama perendaman 4 jam dan persentase CMC 0,4\% (P1C1) yaitu $45,75 \mathrm{e}$ dan aktivitas antioksidan terendah diperoleh pada kombinasi perlakuan lama perendaman 12 jam dan persentase $\mathrm{CMC}$ $0,4 \%(\mathrm{P} 3 \mathrm{C} 1)$ yaitu $11,22 \mathrm{a}$.
Tabel 3. Rerata aktivitas antioksidan $(100 \mathrm{mg} / \mathrm{mL})$

\begin{tabular}{lc}
\hline \multicolumn{1}{c}{ Kombinasi Perlakuan } & \multicolumn{1}{c}{$\begin{array}{c}\text { Rerata } \\
\text { DPPH } \\
(\%)\end{array}$} \\
\hline \hline $\begin{array}{l}\text { P3C2 (Lama Perendaman } \\
\text { 12 jam, CMC 0,6\%) }\end{array}$ & $11,22 \mathrm{a}$ \\
P3C1 (Lama Perendaman \\
12 jam, CMC 0,4\%) \\
$\begin{array}{l}\text { P2C2 (Lama Perendaman } 8 \\
\text { jam, CMC 0,6\%) }\end{array}$ & $14,87 \mathrm{~b}$ \\
$\begin{array}{l}\text { P2C1 (Lama Perendaman } 8 \\
\text { jam, CMC 0,4\%) }\end{array}$ & $15,42 \mathrm{~b}$ \\
$\begin{array}{l}\text { P1C2 (Lama Perendaman } 4 \\
\text { jam, CMC 0,6\%) }\end{array}$ & 26,09d \\
$\begin{array}{l}\text { P1C1 (Lama Perendaman 4 } \\
\text { jam, CMC 0,4\%) }\end{array}$ & 45,75e \\
\hline
\end{tabular}

Keterangan: Angka rerata yang diikuti dengan notasi huruf yang sama menunjukkan pengaruh tidak beda nyata pada uji Tukey

Tabel 3 menunjukkan bahwa uji Tukey masing-masing perlakuan menunjukkan pengaruh beda nyata dengan notasi yang berbeda. Rerata aktivitas antioksidan susu kecambah kedelai juga dapat dilihat pada gambar 4 dibawah ini.

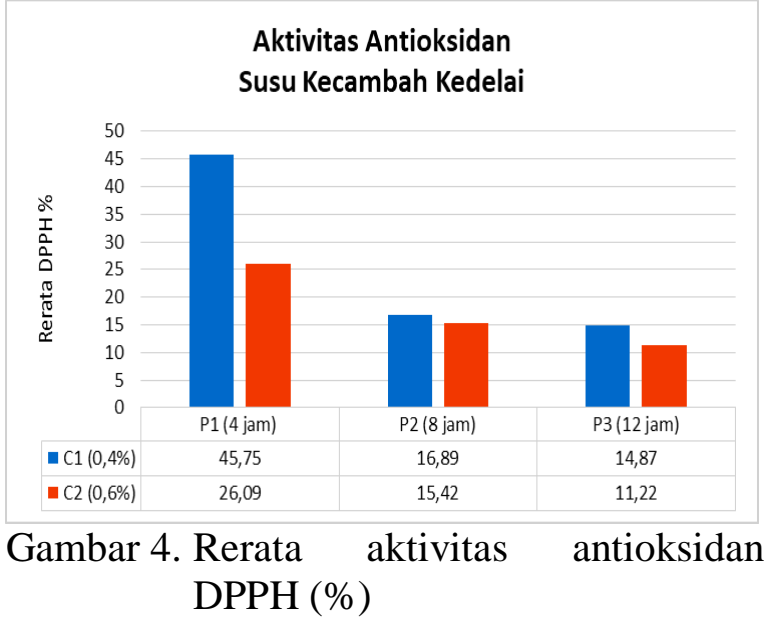

Gambar 4 menunjukkan bahwa semakin lama perendaman maka aktivitas antioksidan pada susu kecambah kedelai semakin menurun. Hal ini sesuai dengan pernyataan. Djaafar et al. (2012) menyatakan bahwa perlakuan perendaman yang dikombinasikan dengan perebusan dapat menurunkan aktivitas antioksidan pada biji. Sedangkan menurut Santosa (2005), semakin 
lama waktu perendaman maka semakin menurunkan kandungan asam fitat dan menurunkan aktivitas antioksidan. Salah satu jenis antioksidan yang terdapat pada bahan pangan adalah vitamin $\mathrm{C}$. vitamin $\mathrm{C}$ mempunyai sifat yang tidak stabil dan mudah larut dalam air (Asgar, 2006).

Gambar 4 juga menunjukkan bahwa semakin banyak persentase penambahan CMC maka semakin turun kandungan aktivitas antioksidan susu kecambah kedelai. Hal ini terjadi karena carboxymethyl cellulose (CMC) merupaka turunan selulosa yang mudah larut dalam air (Muzaifa, 2006). Sehingga CMC mudah dihisrolisis menjadi gula-gula sederhana oleh enzim selulose dan selanjutnya difermentasi menjadi etanol oleh bakteri (Masfufatun et al., 2009). Semakin banyak penambahan CMC maka semakin banyak BAL memanfaatkan substrat yang diubah menjadi asam laktat yang membuat $\mathrm{pH}$ semakin rendah hal ini menyebabkan kandungan vitamin $\mathrm{C}$ semakin stabil pada $\mathrm{pH}$ yang lebih rendah (Maria dan Zubaidah, 2014).

\section{Viskositas}

Dalam penelitian ini viskositas diuji dengan menggunakan viskometer (NDJ-1 viskometer). Berdasarkan hasil analisa sidik ragam menunjukkan bahwa adanya pengaruh tidak beda nyata antara kombinasi perlakuan lama perendaman dan persentase carboxymethyl cellulose (CMC) terhadap viskositas susu kecambah kedelai yang dihasilkan. Rerata viskositas pada berbagai kombinasi perlakuan ditujukan pada tabel 4 . Pada tabel 4 menunjukkan bahwa rerata viskositas pada susu kecambah kedelai dengan kombinasi perlakuan lama perendaman dan persentase CMC berkisar antara 16,16a sampai 32,93d. Viskositas tertinggi diperoleh pada kombinasi perlakuan lama perendaman 12 jam dan persentase CMC $0,6 \%$ (P3C2) yaitu 32,93d dan viskositas terendah diperoleh pada kombinasi perlakuan lama perendaman 12 jam dan persentase CMC 0,4\% (P3C1) yaitu $16,16 a$.
Tabel 4. Rerata viskositas (cps)

\begin{tabular}{lc}
\hline \multicolumn{1}{c}{ Kombinasi Perlakuan } & $\begin{array}{c}\text { Rerata } \\
\text { Viskositas } \\
\text { (cps) }\end{array}$ \\
\hline \hline $\begin{array}{l}\text { P3C1 (Lama Perendaman 12 } \\
\text { jam, CMC 0,4\%) }\end{array}$ & $16,16 \mathrm{a}$ \\
$\begin{array}{l}\text { P2C1 (Lama Perendaman } 8 \\
\text { jam, CMC 0,4\%) }\end{array}$ & $18,83 \mathrm{~b}$ \\
$\begin{array}{l}\text { P1C1 (Lama Perendaman } 4 \\
\text { jam, CMC 0,4\%) }\end{array}$ & $19,73 \mathrm{~b}$ \\
$\begin{array}{l}\text { P1C2 (Lama Perendaman } 4 \\
\text { jam, CMC 0,6\%) }\end{array}$ & $30,50 \mathrm{c}$ \\
$\begin{array}{l}\text { P2C2 (Lama Perendaman } 8 \\
\text { jam, CMC 0,6\%) }\end{array}$ & $31,73 \mathrm{~cd}$ \\
$\begin{array}{l}\text { P3C2 (Lama Perendaman } 12 \\
\text { jam, CMC 0,6\%) }\end{array}$ & $32,93 \mathrm{~d}$ \\
\hline
\end{tabular}

Keterangan: Angka rerata yang diikuti dengan notasi huruf yang sama menunjukkan pengaruh tidak beda nyata pada uji Tukey.

Tabel 4 menunjukkan bahwa uji Tukey masing-masing perlakuan menunjukkan pengaruh beda nyata dengan notasi yang berbeda. Rerata viskositas susu kecambah kedelai juga dapat dilihat pada gambar 5 dibawah ini.

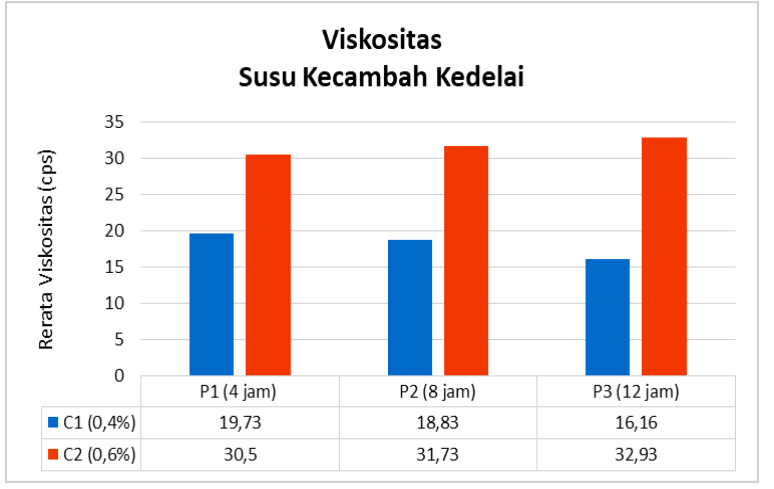

Gambar 5. Rerata viskositas (cps)

Gambar 5 menunjukkan bahwa semakin lama tinggi persentase CMC maka semakin tinggi tingkat kekentalan susu kecambah kedelai. Hal ini sesuai dengan pernyataan Susilowati (2015), yaitu cairan yang dapat mengalir dengan mudah mempunyai viskositas yang kecil dan sebaliknya cairan yang sulit mengalir mempunyai viskositas yang besar. Sedangkan Kamal (2010) menyatakan bahwa keberadaan CMC dalam larutan cenderung membentuk ikatan silang dalam molekul 
polimer yang menyebabkan molekul pelarut akan terjebak didalamnya sehingga terjadi immobilisiasi molekul pelarut yang dapat membentuk struktur molekul yang kaku dan tahan terhadap tekanan. Sehingga dapat disimpulkan semakin tinggi persentase CMC maka pembentukan ikatan silang makin besar dan immobilisasi molekul pelarut juga makin tinggi sehingga menyebabkan viskositas meningkat.

\section{Warna}

Berdasarkan analisis statistik lama perendaman dan persentase penambahan CMC terhadap warna susu kecambah kedelai tidak beda nyata ( $\mathrm{x}^{2}$ tabel $<\mathrm{x}$ hitung). Dari hasil uji organoleptik warna pada susu kecambah kedelai dapat dilihat pada gambar 6.

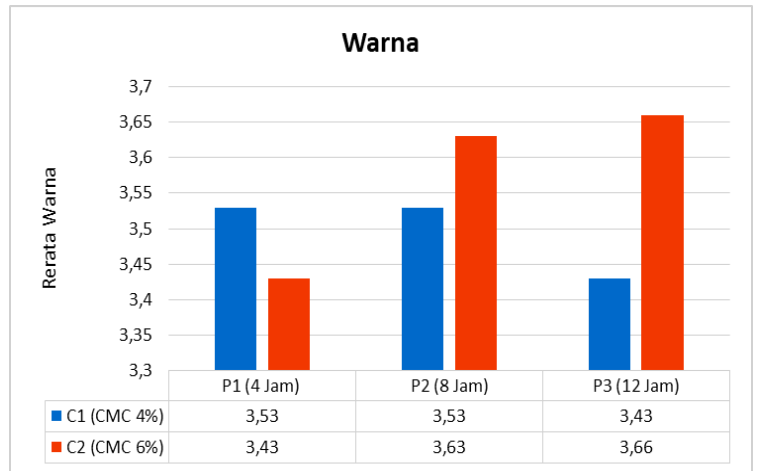

Gambar 6. Rerata warna susu kecambah kedelai

Tingkat kesukaan panelis terhadap warna susu kecambah kedelai berkisar antara 3,43 (agak suka) sampai 3,66 (suka). Tingkat kesukaan terendah terhadap warna susu kecambah kedelai pada perlakuan P3C1 yaitu lama perendaman 12 jam, CMC 0,4\% yaitu 3,43. Dan tingkat kesukaan tertinggi terhadap warna susu kecambah kedelai pada perlakuan $\mathrm{P} 3 \mathrm{C} 2$ yaitu lama perendaman 12 jam, CMC 0,6\% yaitu 3,66. Hal ini sesuai dengan pernyataan Sumarni et al. (2017) penambahan CMC yang bervariasi tidak mempengaruhi kesukaan konsumen terhadap warna, karena CMC berwarna putih, hampir tidak memiliki bau dan rasa.

\section{Aroma}

Berdasarkan analisis statistik lama perendaman dan persentase penambahan CMC terhadap aroma susu kecambah kedelai beda nyata $\left(\mathrm{x}^{2}\right.$ tabel $>\mathrm{x}$ hitung). Dari hasil uji organoleptik aroma pada susu kecambah kedelai dapat dilihat pada gambar 7 .

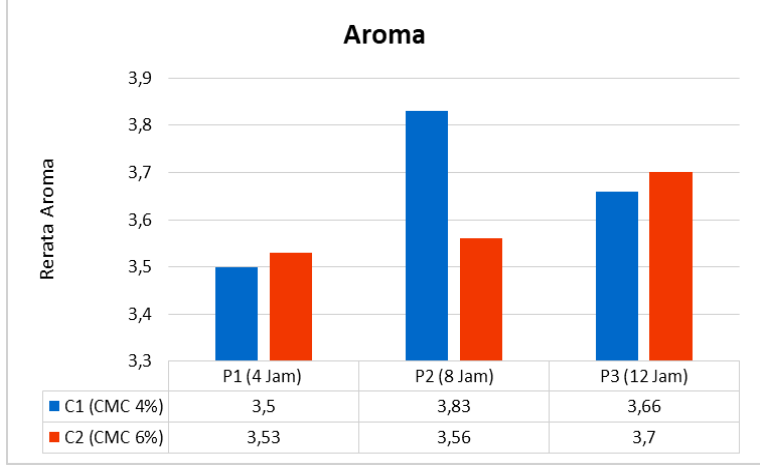

Gambar 7.Rerata Aroma susu kecambah kedelai

Tingkat kesukaan panelis terhadap aroma susu kecambah kedelai berkisar antara 3,50 (agak suka) sampai 3,83 (suka). Tingkat kesukaan terendah terhadap aroma susu kecambah kedelai pada perlakuan P1C1 yaitu lama perendaman 4 jam, CMC $0,4 \%$ yaitu 3,50. Dan tingkat kesukaan tertinggi terhadap aroma susu kecambah kedelai pada perlakuan $\mathrm{P} 2 \mathrm{C} 1$ yaitu lama perendaman 8 jam, CMC 0,4\% yaitu 3,83. Hal ini terjadi karena kandungan protein dengan lama perendaman 4 jam lebih tinggi dan $\mathrm{CMC}$ tidak berwarna dan berbau. Hal ini sesuai dengan pernyataan Suhadi (2003) semakin tinggi kadar protein kedelai mengakibatkan aroma yang kurang disukai karena munculnya bau langu.

\section{Tekstur}

Berdasarkan analisis statistik lama perendaman dan persentase penambahan CMC terhadap tekstur susu kecambah kedelai beda nyata ( $\mathrm{x}^{2}$ tabel $>\mathrm{x}$ hitung). Dari hasil uji organoleptik tekstur pada susu kecambah kedelai dapat dilihat pada gambar 8.

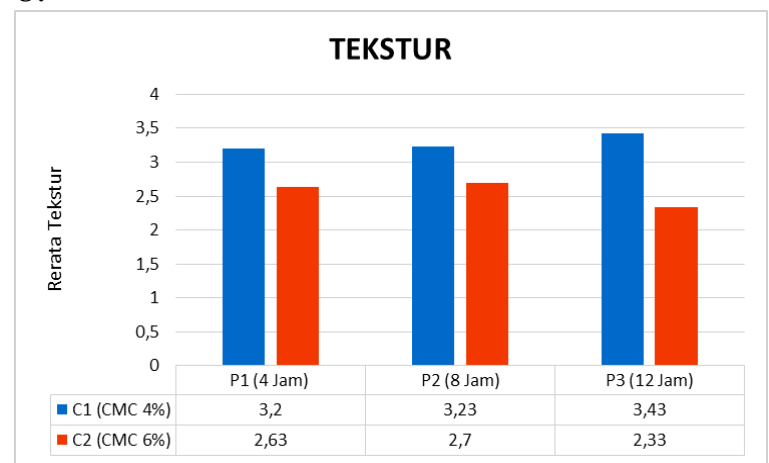

Gambar 8. Rerata Tekstur susu kecambah kedelai 
Tingkat kesukaan panelis terhadap tekstur susu kecambah kedelai berkisar antara 2,33 (tidak suka) sampai 3,43 (agak suka). Tingkat kesukaan terendah terhadap tekstur susu kecambah kedelai pada perlakuan $\mathrm{P} 3 \mathrm{C} 2$ yaitu lama perendaman 12 jam, CMC 0,6\% yaitu 2,33. Dan tingkat kesukaan tertinggi terhadap tekstur susu kecambah kedelai pada perlakuan P3C1 yaitu lama perendaman 12 jam, CMC 0,4\% yaitu 3,43. Semakin banyak persentase penambahan CMC, maka semakin menurunkan tingkat kesukaan panelis. Hal ini dikarenakan CMC adalah salah satu jenis hidrokoloid atau bahan pengental yang dapat meningkatkan viskositas produk pangan (Cahyadi, 2005). Setiyoningrum dan Surahman (2009) menyatakan bahwa semakin besar nilai viskositas maka semakin besar kekentalan suatu produk.

\section{Rasa}

Rasa merupakan parameter yang paling menentukan terhadap daya terima suatu produk pangan (Sumarni et al., 2017). Berdasarkan analisis statistik lama perendaman dan persentase penambahan CMC terhadap rasa susu kecambah kedelai beda nyata ( $\mathrm{x}^{2}$ tabel $>\mathrm{x}$ hitung). Dari hasil uji organoleptik rasa pada susu kecambah kedelai dapat dilihat pada gambar 9 .

Tabel 4. Nilai indeks efektivitas

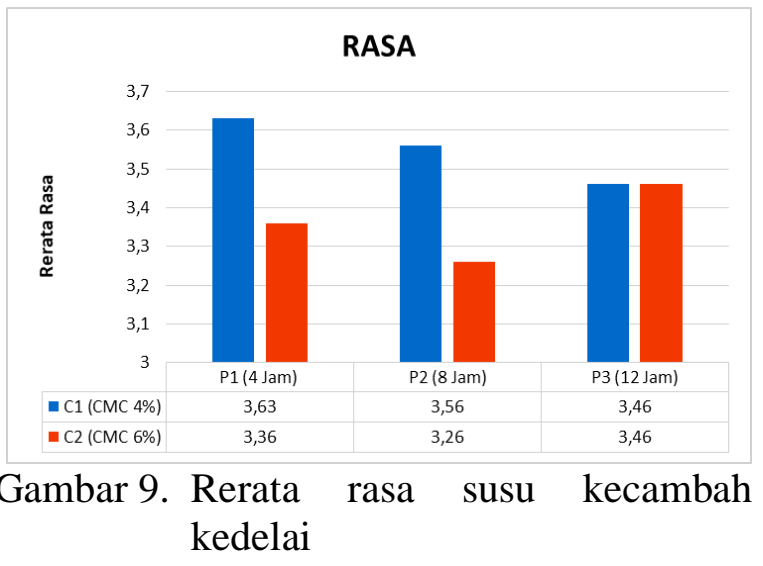

Tingkat kesukaan panelis terhadap rasa susu kecambah kedelai berkisar antara 3,26 (agak suka) sampai 3,63 (suka). Tingkat kesukaan terendah terhadap rasa susu kecambah kedelai pada perlakuan P2C2 yaitu lama perendaman 8 jam, CMC 0,6\% yaitu 3,26. Dan tingkat kesukaan tertinggi terhadap rasa susu kecambah kedelai pada perlakuan $\mathrm{P} 1 \mathrm{C} 1$ yaitu lama perendaman 4 jam, CMC 0,4\% yaitu 3,63. Hasil analisis menunjukkan bahwa ada perbedaan nyata pada setiap perlakuan. Hal ini karena adanya penambahan gula yang dapat memberi rasa manis pada susu kecambah, sedangkan bahan penstabil CMC tidak memberi perubahan rasa karena bahan penstabil tidak berasa (Indriyati et al., 2006).

\section{Perlakuan terbaik}

Hasil perhitungan indeks efektivitas menunjukkan kombinasi perlakuan terbaik pada P1C1 (lama perendaman 4 jam dan persentase $\mathrm{CMC} 0,4 \%$ ) yaitu protein dengan nilai 4,97d, aktivitas antioksidan dengan nilai $45,75 \mathrm{e}$, viskositas dengan nilai $19,73 \mathrm{~b}$, warna dengan nilai 35,33 (suka), aroma dengan nilai 3,50 (agak suka), tekstur dengan nilai 3,20 (agak suka) dan rasa dengan nilai 3,63 (suka).

Kombinasi perlakuan

Nilai produk

\begin{tabular}{lc}
\hline P1C1 (Lama Perendaman 4 jam, CMC 0,4\%) & $0,586^{1^{*}}$ \\
P1C2 (Lama Perendaman 4 jam, CMC 0,6\%) & 0,362 \\
P2C1 (Lama Perendaman 8 jam, CMC 0,4\%) & $0,350^{2^{*}}$ \\
P2C2 (Lama Perendaman 8 jam, CMC 0,6\%) & 0,360 \\
P3C1 (Lama Perendaman 12 jam, CMC 0,4\%) & 0,299 \\
P3C2 (Lama Perendaman 12 jam, CMC 0,6\%) & $0,239^{3^{*}}$ \\
\hline
\end{tabular}

Keterangan: $1^{*}=$ perlakuan terbaik $1 ; 2^{*}=$ perlakuan terbaik $2 ; 3^{*}=$ perlakuan terbaik 3 


\section{KESIMPULAN}

Berdasarkan hasil penelitian dan pembahasan dapat disimpulkan sebagai bahwa: 1) Lama perendaman biji kedelai terbaik dari sifat kimia dengan hasil analisa protein lowry terdapat pada perlakuan P1C1 (lama perendaman 4 jam dan prosentase CMC 0,4\%) dengan nilai 4,97d. Sedangkan hasil analisa aktivitas antioksidan dengan uji DPPH terbaik pada perlakuan P1C1 (lama perendaman 4 jam dan prosentase $\mathrm{CMC}$ $0,4 \%$ ) dengan nilai $45,75 \mathrm{e}$. 2) prosentase carboxymethyl cellulose (CMC) terbaik terhadap sifat fisik (Viskositas) terdapat pada perlakuan $\mathrm{P} 3 \mathrm{C} 1$ (lama perendaman 12 jam dan prosentase CMC $0,4 \%$ ) dengan nilai 16,16a dengan rerata penilaian organoleptik disukai oleh panelis. 3) Lama perendaman biji kedelai dan prosentase Carboxymethyl Cellulose (CMC) terbaik pada susu kecambah kedelai terhadap kandungan kimia, fisik dan organoleptik terdapat pada perlakuan P1C1 (lama perendaman 4 jam dan prosentase CMC 0,4\%) dengan hasil analisa protein dengan nilai $4,97 \mathrm{~d}$, aktivitas antioksidan dengan nilai $45,75 \mathrm{e}$, viskositas dengan nilai $19,73 \mathrm{~b}$, warna dengan nilai 35,33 (suka), aroma dengan nilai 3,5 (agak suka), tekstur dengan nilai 3,2 (agak suka) dan rasa dengan nilai 3,63 (suka).

\section{DAFTAR PUSTAKA}

Alakali, J. S., Okankwo, T. M., \& Lordye, E. M., (2008). Effect of stabilizer on the physic-chemical attributes of thermizad yoghurt. African Jurnal of Biotechnology, 7(2), 153-163.

Anggono, W. A., \& Wahyuni, R. (2017). Studi pengaruh penambahan susu kedelai (Glycine max L.) dan susu jagung manis (Zea mays L. Saccharata) terhadap mutu dan organoleptik es krim. Teknologi Pangan : Media Informasi dan Komunikasi Ilmiah Teknologi Pertanian, 8(1), 1-8. https://doi.org/10.35891/tp.v8i1.2070

Aminah, S., \& Hersoelistyorini, W. (2012). Karakteristik kimia tepung kecambah serealia dan kacang-kacangan dengan variasi blanching. In Prosiding Seminar Nasional \& Internasional, 1(1), 209-217.

Asgar, A., \& Musaddad, D. (2006). Optimalisasi cara, suhu, dan lama blansing sebelum pengeringan pada wortel. Jurnal Hortikultura, 16(3), 245-252.

Astuti, S. (2012). Isoflavon kedelai dan potensinya sebagai penangkap radikal bebas. Jurnal Teknologi \& Industri Hasil Pertanian, 13(2), 126-136.

Cahyadi, (2005). Analisis dan aspek kesehatan bahan tambahan pangan. Jakarta: Bumi Aksara

Cahyani, D. I., \& Rustanti, N. (2015). Pengaruh penambahan teh hijau terhadap aktivitas antioksidan dan kadar protein minuman fungsional susu kedelai dan madu (doctoral dissertation, diponegoro university).

Codex, A. C. (2004). CAC/RCP 57-2004 : Code of hygienic practice for milk and milk products. FAO and WHO, Rome.

Durazzo, A., Gabrielli, P., \& Manzi, P. (2015). Qualitative study of functional groups and antioxidant properties of soy-based beverages compared to cow milk. Antioxidants, 4(3), 523-532.

Djaafar, T. F., Santosa, U., Cahyanto, M. N., \& Rahayu, E. S. (2012). Pengaruh perendaman dan perebusan terhadap kandungan protein, gula, total fenolik dan aktivitas antioksidan kerandang (canavalia virosa). Agritech, 32(3).

Indriyati, Lucia, I. \& Elsy, R. (2006). Pengaruh carboxymethyl cellulose (cmc) dan gliserol terhadap sifat mekanik lapisan tipis komposit bakterial selulosa. Jurnal Sains Materi Indonesia, 40, 1411-1098.

Jiang, S., Cai, W., \& Xu, B. (2013). Food quality improvement of soy milk made from short-time germinated soybeans. Foods, 2(2), 198-212.

Kamal, N. (2010). Pengaruh bahan aditif cmc (carboxylmethyl cellulose) terhadap beberapa parameter pada larutan sukrosa. Jurnal Teknologi, 
1(17), 78-84.

Mardiyanto, T. C., \& Sudarwati, S. (2015). Studi nilai cerna protein susu kecambah kedelai varietas lokal secara in vitro. In Prosiding Seminar Nasional Masyarakat Biodiv Indonesia, 1(5), 1256-1264.

Muzaifa, M. (2006). Pembuatan cmc (carboximethyl cellulose) dari sellulosa bakterial (nata de coco). Jurnal Agrista, 10(2), 100-106.

Masfufatun, Widaningsih, Kumala, N. \& Rahayuningsih, T. (2009). Pengaruh suhu dan waktu penyimpanan terhadap vitamin $c$ dalam jambu biji (psidium guajava). Universitas Wijaya Kusuma, Surabaya.

Maria, D. N., \& Zubaidah, E. (2014). Pembuatan velva jambu biji merah probiotik (lactobacillus acidophilus) kajian persentase penambahan sukrosa dan cmc [in press oktober 2014]. Jurnal Pangan dan Agroindustri, 2(4), 18-28.

Pertiwi, S. (2013). Aktivitas antioksidan, karakteristik kimia dan sifat organoleptik susu kecambah kedelai hitam (glycine soja) berdasarkan variasi waktu perkecambahan. Jurnal Pangan dan Gizi, 04(8) 1-8.

Pramita, R. I., (2017). Pengaruh waktu perkecambahan terhadap peningkatan nilai gizi susu kecambah kedelai (glycine max). Bogor (ID): Fakultas Teknologi Pertanian Institut Pertanian Bogor.

Prasetya, B. B., Purwadi, \& Rosyidi, D. (2015). Penambahan cmc (carboxy methyl cellulose) pada pembuatan minuman madu sari buah jambu merah (psidium guajava) ditinjau dari ph, viskositas, total kapang dan mutu organoleptik. Universitas Brawijaya, Malang. p. 1-8.

Santosa, C. M., \& Triana, H. (2005). Kandungan senyawa kimia dan efek ekstrak air daun bangunbangun (coleus amboinicus, 1.) Pada aktivitas fagositosis netrofil tikus putih (rattus norvegicus). Majalah Farmasi
Indonesia, 16(3),141-148.

Setiyoningrum, F., \& Surahman., D. N. (2009). Pengaruh penggunaan tomat apel belum matang terhadap mutu pasta tomat di pt. mitra aneka food kuningan. LIPI BSS, 235(2), 1-6.

Suhadi, I. (2003). Pengaruh lama perendaman kedelai dan jenis zat penggumpal terhadap mutu tahu. Digitized By Usu Digital Library, 1-6.

Susilowati, D. (2015). Pengaruh Air Rebusan Kayu Secang Dalam Penyembuhan Biang Keringat Pada Bayi . Jurusan Kebidanan. Surakarta.

Sumarni, S., Muzakkar, M. Z., \& Tamrin. (2017). Pengaruh penambahan cmc (carboxymethyl cellulose) terhadap karakteristik organoleptik, nilai gizi dan sifat fisik susu ketapang (terminallia catappal.). Jurnal Sains Dan Teknologi, 2(3), 604-614.

Tripamungkas, A. (2015). Pengaruh penambahan carboxymethyl cellulose (cmc) terhadap sifat dan kesukaan minuman sari kacang hijau (phaseolus radiatus 1) (Doctoral dissertation, Universitas Gadjah Mada).

Wea, A. S. Y., Widodo, R., \& Pratomo, Y. A. (2014). Evaluasi kualitas produk susu kecambah kacang hijau, kajian dari umur kecambah dan konsentrasi na-cmc. Jurnal Teknik Industry Heuristic, 11(1), 61-79. 